\title{
MECHANISMS OF NON-TARIFF BARIERS IN AGRI-FOOD TRADE BETWEEN POLAND AND THE CZECH REPUBLIC ON THE INTRA-EU MARKET
}

\author{
ADAM A. AMBROZIAK \\ RENATA GROCHOWSKA
}

\begin{abstract}
The paper aimed identification of mechanisms of non-tariff barriers used by the EU Member States that affect the intra-EU exchange of agri-food products on the example of the trade between Poland and the Czech Republic. In the beginning the paper presents, the main theoretical assumptions of the free movement of goods, based on subsequent economic integration stages according to Balassa. Next it discusses, examples of the identified actions of the Czech Republic against the agri-food products imported from Poland, together with an analysis of potential economic mechanisms resulting from these activities. The next section presents the statistical effects of trade exchange, which allows us to formulate conclusions regarding the potential consequences of the barriers.

On the basis of the analysis, it was found that soft non-tariff barriers on the Czech market have not brought any significant negative effects for the overall Polish exports of agri-food products to the Czech Republic The negative consequences have been borne by individual traders, who according to the Czech authorities offered products that do not meet the requirements. Moreover, our study identified traditional non-tariff barriers introduced on the Czech market for export of all food suppliers which led to the collapse of exports from Poland, while at the same time the growth of the main suppliers from other EU Member States continued to grow.
\end{abstract}

Keywords: EU internal market, protectionism, agri-food products, Poland, Czech Republic, trade.

JEL codes: F10, F13, F14, F15.

Dr hab. Adam A. Ambroziak, prof. SGH, Warsaw School of Economics (SGH), Jean Monnet Chair of European Integration, Collegium of World Economy; al. Niepodległości 162, 02-554 Warsaw (adam.ambroziak@sgh.waw.pl).

Dr hab. Renata Grochowska, prof. IERiGŻ-PIB, Institute of Agricultural and Food Economics - National Research Institute, Food Industry Economics Department; ul. Świętokrzyska 20, 00-002 Warsaw (renata.grochowska@ierigz.waw.pl). 


\section{Introduction}

A wide range of scientific research confirms the validity of economic theories pointing to the disclosure of the benefits of trade. Hence, in the last few decades, we can observe a strong tendency to economic integration in the formula of stages indicated by Balassa (1961). It is worth noting that these considerations apply to all products: both industrial and agri-food, although the latter are regarded as very sensitive. This is mainly due to their seasonality, high market failure and intervention of the countries. As a consequence, most trade agreements, including those concluded by the European Union, concern primarily preferences with regard to trade in industrial goods, and, to a lesser extent (or not at all), liberalisation of trade in agri-food products. Also, the average rates applied under the most favoured nation clause, used by the most developed countries in the world, are much higher for imports of agri-food products than for industrial goods ${ }^{1}$.

Reluctance to complete liberalisation of agri-food trade can also be noted in the process of European economic integration. Barriers are still in place which, due to the functioning of the internal market and the lack of customs controls at the internal EU borders, have non-tariff character, thus making their consequences especially difficult to identify and quantify. In addition, the effects of introducing barriers are not only commercial as they go beyond the concept of a strictly free trade area or Customs Union. Their severity is observed during periods of economic crises, like the last one that hit the EU in 2008-2010. However, after this period, many of the EU Member States have continued to apply protectionist and interventionist concept of national economic policy, which results in inflation of the above barriers.

In this context, the analysis should cover the actions taken by the Czech Republic towards imported food, including food imported from Poland. At least three conditions determining trade exchange between these countries can be named. Firstly, the Czech Republic does not have self-sufficiency in the agrifood production and therefore it is forced to import them from other countries, in particular from the EU. The self-sufficiency of the Czech Republic, which is expressed in the share of domestic production and domestic consumption, is positive in cereals, rape, sugar and milk, and negative in vegetables, pork and poultry. This trend is steadily deepening. Production of pork satisfies $60.8 \%$ of domestic demand, while vegetable production - only $36.9 \%$ (EU Office ĆS, 2016). Secondly, Poland, is presently ranked second (behind Germany), in terms of value, among the suppliers of food products on the Czech market, due to both the production capacity and geographic location. Thirdly, the Czech Republic, following Germany, the Netherlands and the United Kingdom, is a very important - fourth - recipient of the Polish agri-food products with the share at $7.3 \%$ in $2004,8.7 \%$ in 2012 and $6.7 \%$ in 2017.

\footnotetext{
${ }^{1}$ Most favoured nation clause, MFN - the concept relating to the inter-state trade of goods. The country granting this clause to other state gives it the powers and facilities not less than any other state, with which it trades.
} 
Therefore, it can be expected that despite (or maybe because of) the lack of self-sufficiency, the Government of the Czech Republic - in order to foster its own producers - is willing to take protectionist action against imported food. Taking the above into account, the aim of this article is to identify non-tariff barrier mechanisms affecting the intra-EU trade in agri-food products between Poland and the Czech Republic. The study considers also the dynamics of food imports from four other key suppliers of food to the Czech market. The review was conducted on the basis of legislation and strategic documents as well as source literature, using the method of the review and critical analysis of source materials.

The first part presents the main theoretical assumptions of the free movement of goods based on subsequent stages of economic integration according to Balassa. Afterwards, the discussion covers certain examples of the identified activities of the Czech Republic with reference to the agri-food products imported from Poland, together with an analysis of potential economic mechanisms resulting from these activities. The next part presents the statistics of trading, which allowed capturing the potential effects of the barriers being introduced for the trade, in contrast to liberalization processes under the economic integration. Finally, conclusions include the potential consequences of using selective barriers in trade.

\section{Theoretical background of the free movement of goods}

Economic integration, according to the traditional approach of Balassa, is considered from the point of view of eliminating discrimination between entities in international relations (both as a state: non-discrimination and the process: taking action to stop discrimination). Starting with the liberalisation of the movement of goods, through the services and factors of production, to the introduction of fixed exchange rates, determine the next so-called stages of economic integration (Balassa, 1961; Sapir, 2011). The first two of them relate to the creation of the integration grouping in the form of a free trade area and Customs Union by eliminating the traditional barriers to trade. This includes the prohibition of customs duties and measures having a similar effect, as well as quantitative restrictions and methods of equivalent effect in trade between the partners forming integration grouping. In the case of the Customs Union, an essential element, the so-called positive integration is the introduction of a uniform customs duties in trade with third countries. The next stage of economic integration is a common market, which is manifested by communitarisation of certain policies, including trade, as well as introduction of the so-called four freedoms: movement of goods, services, labour and capital. When it comes to trade in goods, it should be done freely without any restrictions. However, it is only in practice that three barriers have been defined within the European Union, the elimination of which should ensure the aforementioned freedom: physical, technical and fiscal. As the final stage of economic integration, the economic and Monetary Union is mentioned, which, through the introduction of fixed exchange rates (and subsequently also the common currency) should also eliminate the remaining obstacles to trade. 
The establishment of the aforementioned economic integration stages results in specific economic and social effects (Weststrate, 1948; Lipsey, 1960; Molle, 2006; Magee, 2008; Ambroziak and Kaliszuk, 2009; Ambroziak, 2016). Traditionally, they are classified as static (affecting production efficiency and benefits of consumers) and dynamic (associated in the long run with the rate of economic growth) (Viner, 1950; Balassa, 1967, 1974; Sapir, 2011; Carbaugh, 2014; Barcz, Kawecka-Wyrzykowska and Michałowska-Gorywoda, 2016). In the case of a deep and extended integration there are also the short-run and long-run effects, which is associated especially with the consequence of the liberalisation of capital movements (Baldwin, 1989). The difference between the short run and the long run can be found in the exogeneity or endogeneity of factor endowments. Whereas a medium run can be further distinguished, when capital is already mobile but there are still restrictions to the mobility of labour (Marques, 2008).

From the point of view of the theory of the Customs Union, in case of the static effects, it is primarily about the effects of creation and diversion. In the classical approach, the trade creation effect represents the additional import from countries belonging to the integration grouping, as a result of the reduction in import prices resulting from the elimination of customs duties and other traditional marketing restrictions. It appears when the national production in a country liberalising access to its market, is replaced by imports from another Member State subjected to trade preferences. Therefore, the elimination of the existing barriers, previously protecting from importing more competitive goods, makes part of the production of the importing country become ineffective. However, this does not mean a loss on the side of the country opening its market, since assuming full use of the resources, both before and after creating the Customs Union or free trade area, it should be followed by increase in wealth of all countries participating in this process, thanks to the specialization in production based on comparative advantage (Salvatore, 2014; Barcz et al., 2016).

Trade creation within the integration grouping could mean access to a wider range of potentially cheaper products manufactured in another country of a free area or Customs Union. From the point of view of demand, this is the so-called effect of consumption, due to the possibility of acquiring more goods at a lower price or saving funds for other goods. In the latter case, demand may be directed partly to goods from outside the grouping, which may somewhat limit the negative consequences of the trade diversion effect. Finally, it comes to boosting the consumption in the area of the integrated economic organism, which may result in employment growth, reduction of unemployment, improvement of the competitive position of enterprises through increased productivity and, as a result, in economic growth. However, on the part of the importing country, whose ineffective producers cannot withstand competition from other countries of the free trade zone or Customs Union, the means of production are released (workforce and capital) that - in the face of a much larger and diversified market - allows for their better use (Salvatore, 2014; Barcz et al., 2016). 
When it comes to the trade diversion effect of the Customs Union, it is the increase in imports from the countries subject to preferential treatment at the expense of suppliers outside integration groupings. This is sparked off by the elimination of customs duties on imports from the new supplier-country subject to the preferences of the Customs Union, while maintaining or introducing new trade barriers to partners from third countries. Therefore, the diversion trade effect is taking place in the event of a reduction in the overall cost of imports from a Member State belonging to the Customs Union in relation to costs of imports from a supplier outside the integration grouping. Nevertheless, it should be noted that this does not have to result from greater price competitiveness of the producer covered by preferences, but rather from a relative rate of duties and other charges imposed in trade with existing partners from countries outside the integration grouping. Consequently, the diversion trade effect is definitely more bounded with preference given to partners within the framework of the free trade area or Customs Union.

In a traditional analysis of the theory of the Customs Union, it is assumed that this effect reduces the general wealth and deteriorates the international allocation of resources, as it moves production from a more efficient manufacturer located outside of an integration grouping to a less efficient one, who is covered by trade preferences (Aitken, 1973; Kawecka-Wyrzykowska and Rosati, 2003). It is worth noting, though, that in some studies this view was criticised because, as it has been shown, in some situations the diversion trade effect may lead to an increase in overall wealth (Lipsey, 1960; Wonnacott, 1996; Cheong and Wong, 2007). What should be also noted are Balassa's findings stating that trade creation has been the main feature in manufacturing goods, whereas agricultural products have witnessed considerable trade division (Balassa, 1974).

The second category of effects - dynamic - concerns the effects on the economy, the appearance of which requires more time. In addition, it is assumed that they are much more important for the investment position as well as for competitiveness and economic growth. It includes such phenomena as: GDP growth, the influx of new technologies and the associated technological progress, increased competition, the effects of scale, learning companies, improving investment attractiveness of larger sales markets, improvement of productivity, change in the structure of industry due to the specialization strengthened by the use of comparative advantages in trade, as well as the increase in revenues resulting from the use of knowledge (Makower and Morton, 1953; Verdoorn, 1954; Balassa, 1966; Rivera-Batiz and Romer, 1991; Kawecka-Wyrzykowska and Rosati, 2003). It is also assumed that, due to the fact that a small change in the growth rate can lead to a substantial cumulative effect on national output, the dynamic effects of trade policy changes can yield substantially larger magnitudes than those based on static models (Carbaugh, 2014).

The strength of the above-mentioned effects, primarily commercial ones, depends largely on the factors mentioned, including (Balassa, 1961; Panagariya, 2000; Burfisher, Robinson and Thierfelder, 2001; Ładyka, 2001; Kawecka-Wyrzykowska and Rosati, 2003; Magee, 2008; Marques, 2008; Salvatore, 2014; Carbaugh, 2014; Barcz et al., 2016): 
- Degree of significance of eliminated barriers, e.g. relative changes in the rates of customs duty applied in mutual trade and to partners from third countries,

- Length of the transition period necessary to implement integration solutions;

- Current trade links between business partners, including the share of individual products in the trade of the importing and exporting country;

- Nature, scope and depth of new political, social and economic ties, including trade as well as institutional links between the countries forming an integration grouping;

- Amount and type of barriers used in trade with third countries;

- Differences in the costs of production, taking into account transaction costs;

- Price elasticity of demand and supply in both exporting and importing country,

- Flexibility of supply of substitutes in the importing country;

- Complementarity or competitiveness (the intensity of competition) of individual economies;

- Degree of intra-industry specialisation;

- Differentiation in the level of economic development, the structure of economy and the size of markets;

- Potentially occurring distortions of economic relations (political, social and economic);

- Degree of development of economic infrastructure and the proximity of economic partners and the associated costs of transport;

- Distribution of benefits and losses between the Member States in connection with the establishment of the integration groupings;

- Economic policy conducted against both domestic and foreign producers and investors.

The above-effects can be reduced by liberalisation or even eliminated in connection with the introduction of barriers in the trade between the members of the economic organism. National regulations hindering or preventing the introduction of goods to trading on another national market are in clear contradiction to the idea of free trade, limiting or eliminating the benefits of trade both on the part of the supplier (in particular an entrepreneur - producer) and the recipient (in particular, a customer).

\section{Selected barriers applied in the Czech Republic with reference to agri-food products from Poland}

\section{Examples of hidden barriers to trade}

The criticism of Polish food in the Czech Republic has started in the so-called salt scandal, which came into the spotlight in February 2012, when it was revealed that three Polish companies have been selling industrial salt as common salt for 10 years. Other irregularities concerned banned antibiotics in meat, banned acids in pickles, rat poison in wafers, and pesticide in mushrooms. It was then that the Czech Agriculture and Food Inspection Authority - CAFIA² (Czech: Státní Zemĕdĕlská

${ }^{2}$ CAFIA is a state administration body subordinate to the Ministry of Agriculture. It is a state authority responsible for supervision of safety, quality and labelling of foodstuffs. 
A Potravinařská Inspekce) warned consumers against buying food from Poland, while the Czech Minister of Agriculture announced activities aimed at organisation of the next summit of the European Council to discuss the possibility of banning sales (import) of food from Poland (Heath, 2012).

In the face of suspicions concerning subsequent cases of inadequate quality or health-threatening food on the Czech market, the State Veterinary Administration and CAFIA launched, in the same year (2012), a special website (www.potravinynapranyri.cz) (Food Pillory). It enables search for such foreign food products broken down into three categories of products, i.e. dangerous, adulterated and of insufficient quality. The latter is a subjective assessment based on unspecified criteria. Currently, the database includes information about twenty-two dangerous products from Poland (5 products of poor quality, including butter, cheese, chocolate and chicken; 6 adulterated products, for which the information on the label does not match the weight or the actual ingredients, including potatoes, wafers, ketchup produced for one of the hypermarkets, herring salad; and 11 unsafe products, because of: excess of pesticides, pathogens Salmonella or foreign bodies, e.g. turkey minced meat products, fresh chicken breasts, cauliflowers, chicories, apples and carrots) (Potravinynapranyri.cz, 2017).

The analysis of the available data on the number of food cases, identified by the Czech Republic as not meeting the standards, does not allow us to explicitly conclude discriminatory practices only against imports from Poland (although taking into account absolute numbers, the largest number of records concerns Polish food). Taking into account the share of a particular country in the overall imports of agri-food sector of the Czech Republic and the share of the products originating in that country in relation to the number of all the contested goods (3852) the worst situation (it was stated that relatively greater share of contested agri-food products in relation to the share of the given country in the imports of the country to the Czech market) is observed in Hungary, Spain, Turkey, India, Bulgaria, Serbia, Greece, Vietnam, Cyprus and Australia (Table 1). 
Table 1

The geographical structure of Czech agri-food import and products considered poor quality, adulterer or dangerous on the Czech market in 2012-2016

\begin{tabular}{|c|c|c|c|c|c|c|c|}
\hline Country & $\begin{array}{l}\text { Share } \\
\text { in the } \\
\text { import } \\
\text { of the } \\
\text { Czech } \\
\text { Republic }\end{array}$ & $\begin{array}{l}\text { Number } \\
\text { of } \\
\text { products }\end{array}$ & $\begin{array}{l}\text { The } \\
\text { percentage } \\
\text { of the total } \\
\text { number } \\
\text { of products } \\
\text { considered } \\
\text { as faulty }\end{array}$ & Country & $\begin{array}{l}\text { Share } \\
\text { in the } \\
\text { import } \\
\text { of the } \\
\text { Czech } \\
\text { Republic }\end{array}$ & $\begin{array}{c}\text { Number } \\
\text { of } \\
\text { products }\end{array}$ & $\begin{array}{l}\text { The } \\
\text { percentage } \\
\text { of the total } \\
\text { number } \\
\text { of products } \\
\text { considered } \\
\text { as faulty }\end{array}$ \\
\hline & A & B & $\mathrm{C}$ & & A & B & $\mathrm{C}$ \\
\hline Germany & $29.6 \%$ & 133 & $3.45 \%$ & Taiwan & $0.4 \%$ & 8 & $0.21 \%$ \\
\hline Poland & $9.2 \%$ & 276 & $7.17 \%$ & Singapore & $0.4 \%$ & 0 & $0.00 \%$ \\
\hline Slovakia & $6.9 \%$ & 198 & $5.14 \%$ & Kazakhstan & $0.3 \%$ & 0 & $0.00 \%$ \\
\hline China & $6.5 \%$ & 62 & $1.61 \%$ & Malaysia & $0.3 \%$ & 1 & $0.03 \%$ \\
\hline Netherlands & $5.7 \%$ & 39 & $1.01 \%$ & Portugal & $0.3 \%$ & 1 & $0.03 \%$ \\
\hline Austria & $4.1 \%$ & 34 & $0.88 \%$ & India & $0.3 \%$ & 21 & $0.55 \%$ \\
\hline Italy & $4.0 \%$ & 92 & $2.39 \%$ & Finland & $0.3 \%$ & 0 & $0.00 \%$ \\
\hline $\begin{array}{l}\text { Russian } \\
\text { Federation }\end{array}$ & $3.3 \%$ & 3 & $0.08 \%$ & Bulgaria & $0.2 \%$ & 35 & $0.91 \%$ \\
\hline France & $3.1 \%$ & 33 & $0.86 \%$ & Serbia & $0.2 \%$ & 25 & $0.65 \%$ \\
\hline Hungary & $2.8 \%$ & 141 & $3.66 \%$ & Luxembourg & $0.2 \%$ & 2 & $0.05 \%$ \\
\hline $\begin{array}{l}\text { United } \\
\text { Kingdom }\end{array}$ & $2.5 \%$ & 16 & $0.42 \%$ & Lithuania & $0.2 \%$ & 2 & $0.05 \%$ \\
\hline Belgium & $2.5 \%$ & 15 & $0.39 \%$ & Mexico & $0.2 \%$ & 2 & $0.05 \%$ \\
\hline Spain & $1.7 \%$ & 67 & $1.74 \%$ & Greece & $0.2 \%$ & 20 & $0.52 \%$ \\
\hline South Korea & $1.6 \%$ & 3 & $0.08 \%$ & Vietnam & $0.1 \%$ & 40 & $1.04 \%$ \\
\hline $\begin{array}{l}\text { United } \\
\text { States }\end{array}$ & $1.4 \%$ & 30 & $0.78 \%$ & Canada & $0.1 \%$ & & $0.00 \%$ \\
\hline Hong Kong & $0.9 \%$ & 0 & $0.00 \%$ & Israel & $0.1 \%$ & 4 & $0.10 \%$ \\
\hline Romania & $0.9 \%$ & 4 & $0.10 \%$ & Croatia & $0.1 \%$ & 4 & $0.10 \%$ \\
\hline Japan & $0.9 \%$ & 3 & $0.08 \%$ & Latvia & $0.1 \%$ & 0 & $0.00 \%$ \\
\hline Sweden & $0.9 \%$ & 0 & $0.00 \%$ & South Africa & $0.1 \%$ & 2 & $0.05 \%$ \\
\hline Azerbaijan & $0.8 \%$ & 0 & $0.00 \%$ & Belarus & $0.1 \%$ & 0 & $0.00 \%$ \\
\hline Ireland & $0.8 \%$ & 4 & $0.10 \%$ & Indonesia & $0.1 \%$ & 0 & $0.00 \%$ \\
\hline Switzerland & $0.8 \%$ & 2 & $0.05 \%$ & Brazil & $0.1 \%$ & 2 & $0.05 \%$ \\
\hline Denmark & $0.7 \%$ & 0 & $0.00 \%$ & Cyprus & $0.1 \%$ & 5 & $0.13 \%$ \\
\hline Turkey & $0.7 \%$ & 80 & $2.08 \%$ & Bangladesh & $0.1 \%$ & 0 & $0.00 \%$ \\
\hline Ukraine & $0.6 \%$ & 0 & $0.00 \%$ & Philippines & $0.1 \%$ & 0 & $0.00 \%$ \\
\hline Thailand & $0.6 \%$ & 8 & $0.21 \%$ & Estonia & $0.1 \%$ & 0 & $0.00 \%$ \\
\hline Slovenia & $0.6 \%$ & 8 & $0.21 \%$ & Australia & $0.1 \%$ & 6 & $0.16 \%$ \\
\hline
\end{tabular}

Source: own study based on Eurostat and Potravinynapranyri.cz (2017). 
Placement of a product on the list implies negative consequences for the producer and supplier of a given product. When analysing the above data, three issues should be kept in mind. Firstly, products are entered onto the list in a decidedly selective manner which directly impacts exports of a given operator. Secondly, it should be noted that media reports about irregularities pertaining to such sensitive products as food, may also have a negative impact on the perception of all other products from the given country. Thirdly, the popularity of the website among Czech consumers remains unknown. It is, however, difficult to imagine Czechs to check it with respect to food safety prior to every shopping. Especially bearing in mind that food security is, actually, the headache of the state.

Critical opinions about the quality of the Polish food were also noted in subsequent years. In February 2013, the Czech inspectors informed about finding traces of horse meat in hamburgers and in beef and pork imported from Poland. Not denying this, the results of an EC-commissioned test should be brought to light. The test checked beef samples across the EU and found horse DNA in 3.90\% of Polish samples, which was below the EU average amounting to 4.66\% (Richter, 2013). Then, in April, the Czech State Veterinary Administration informed about finding phenylbutazone in the horsemeat, which is a pain killer for race horses. This should definitely not be used in food products due to its negative effects on human health (Richter, 2013).

Some of the allegations addressed to Polish products concerned misleading the consumers by the sellers who placed a "Czech Quality" (cz Česká Kvalita) tag with the Czech flag next to the Polish products. First of all, these tags had nothing to do with the government programme under the same name, which aims to create a unified system that makes it possible to highlight trusted and independent quality labels based on objective third-party product or service verification and to exclude non-compliant brands that are misleading for consumers. Secondly, the requirements associated with this programme apply to ensure the highest quality products, constantly verified by independent bodies, and in no case relate to the place of origin of the goods (as noted by CAFIA) (Ceskakvalita.cz, 2018). Such actions are an overinterpretation of the national regulations, while placing products on the misleading list is an instrument, which is directed against the individual Polish producers, instead of sellers (large retail chains).

Another stage of the criticism of the Polish food in the Czech Republic were allegations, by the Czech Minister of Agriculture in July 2016, suggesting that Polish producers of eggs used price dumping. It should be noted that the concept of dumping in trade in the internal market within the framework of the Customs Union does not exist in connection with the free movement of goods. Consequently, any price negotiations are held with the consent of specific customers and suppliers. In his opinion the Czech Republic produces around 2 billion eggs a year - just around enough to meet local demand. However, egg imports were estimated in 2015 to have reached around 800 million, around 120 million more than in the previous year. According to the Czech producers those imported eggs were being sold at less than production costs. Additionally, many of the imports are not labelled properly, 
they failed to give details about their country of origin and type of production methods. The Ministry of Agriculture said it was forced to return around 160,000 eggs to Poland in June, because these markings were absent. This followed hard on the heels of problems with around half a million Polish eggs a month earlier (Johnstone, 2016).

Another example of problems of the Polish food on the Czech market was the sales of the "Loyd" tea with a taste of mint and cranberry with herbs produced by the Polish company Mokate S.A. in the Albert store chain, which was highly publicized at the end of 2016. According to the Czech CAFIA, the hallucinogenic substances were detected in tea, in the amount of 206 micrograms of atropine and 31.7 micrograms of scopolamine per kilogram of the product. Although the Polish producer presented shelf-life tests, the stores began to withdraw the product from sale (Pospihal, 2016). These activities can be related to the fact that in 2005 the Polish company - Mokate, bought Dukat - a Czech tea manufacturing company selling teas under the Zlaty vyber brand. Dukat was at that time one of the largest companies on the Czech tea market. The move was aimed at establishing a bridgehead for Mokate's expansion onto the EU markets.

The above-presented actions of the Czech Republic related to the very sensitive sector of agri-food products. Undermining the quality and safety of one product from a given country may be treated as an example of soft non-tariff barriers. This is because consequences of their introduction result not only in the restriction of sales of this product on the market, but under the spillover effect, other food suppliers may be affected, although their products have not been contested, and the earlier increase in trade flows can be significantly reduced. In addition, critical opinions relating to a given food can be followed up by other countries interested in restricting access to their market, as well as acknowledging the author's critical opinions. As a consequence, significant impediments in entering the market not only of the country publicising the cases of irregular products, but also other existing recipients can be expected (example of the first Russian embargo on the import of Polish apples due to exceeded standards of chemicals, e.g. Ambroziak, 2017).

\section{Czech authorities within the framework of the so-called economic patriotism}

The concept of economic patriotism comes down to promote products offered and produced by domestic entrepreneurs. At times, not only the origin of the product, but also capital is emphasized, which would improve the position of national companies in relation to foreign companies (including investors). In the framework of such actions, as of 1 January 2015, the Czech Republic has introduced the requirement for larger retailers (with a turnover of over CZK 5 billion) to provide information "visible at the entrance to the stores" about the origin and shares of the five largest food suppliers in a given store ${ }^{3}$. This solution was particularly severe for large stores, because small ones, having a much smaller range of products, most

\footnotetext{
${ }^{3}$ Article 3b par. 4 of the Law of 24 June 1997 (110/1997) on food and tobacco products and amending and supplementing certain related laws as amended by the Law No. 139/2014.
} 
often supplied themselves on the domestic market. Taking into account the fact that Poland is one of the largest exporters of food to the Czech market, it would be often in the mentioned group. Having regard to the negative message in the Czech media about the quality of Polish food, it can be presumed that larger dealers could either resort to repackaging it so to be able to serve Czech origin, or limit sales. Ultimately, the provision, due to the frequent misleading of consumers and after the intervention of the European Commission, was withdrawn in September $2016^{4}$.

Another example of actions aimed at highlighting the national origin of products, are new requirements, which have been introduced from 1 January 2017 and which narrow down the principles for labelling food products originating in the Czech Republic $^{5}$. The primary purpose of the change is to terminate practices of labelling products as "Czech only", when they are packed in the Czech Republic or prepared "according to the Czech recipe". In the case of milk, wine and unprocessed food (such as meat, vegetables or fruit) the seller will be able to mark it as "Czech only" if it was produced in the Czech Republic and, at the same time, it comes entirely from Czech raw materials. In the case of composite products (e.g. sausages), at least $75 \%$ of the raw materials used must come from the Czech Republic. Producers not meeting the conditions, will not be allowed to use "other information - mainly verbal, visual or graphic - suggesting that the country of origin of the food is the Czech Republic" (Juhảsz, 2016, p. 1). The amendment also takes into account the fact that in some cases, it is not possible to supply Czech raw materials, as they do not exist in the Czech Republic - for example, for chocolate to be considered a Czech product, it is enough for it to be manufactured on the territory of the Czech Republic. Any discrepancies will be investigated by CAFIA, which may impose penalties up to CZK 10 million (i.e. approx. EUR 370 thousand) (WPHiI, 2016).

The activities presented above are clearly associated with the so-called economic patriotism. Without the discussion on economic rationality of this concept, it is worth noting that its effectiveness, however, depends on consumers sharing these values, as well as on their actions during shopping. Then it may turn out that being accustomed with the imported products, their high quality and price competitiveness may prevail over the willingness to support their own producers. Therefore, these activities may be counted among the soft non-tariff tools that, nonetheless, leave the final decision concerning the purchase of the given items to the consumers. But then, in the period of growing protectionist and national trends, these types of slogans are increasingly promoted in public space, which may generally limit the positive attitudes of consumers towards the import of goods, thanks to which they have a greater choice, and with the competition with domestic producers, potentially lower prices. Such concepts may, therefore, lead to closing of the markets, and thus to the inducing of adverse effects to the positive effects of the Customs Union.

\footnotetext{
${ }^{4}$ European Commission sent to the Czech Republic a formal notice on 18 June 2015, and after the amendment of the law, closed the case on 17 November 2016.
}

${ }^{5}$ Par. 9b of the Law of 24 June 1997 (110/1997). 


\section{Additional controls of food as an example of administrative barriers}

The protectionist actions of the Czech authorities towards food imported from Poland are confirmed by the introduction of a special CAFIA instruction of August 2014 requiring particularly thorough sanitary inspection of the Polish food products, especially apples, meat and meat products, milk and dairy products and fish. The aforementioned instruction did not include products from other EU countries, which was a clear action contrary to the EU principle of non-discrimination. The Czech inspectors collected 4500 samples of Polish products this year, which was about 1400 more than just from Spain. Polish food products rank second in terms of the total amount of collected samples even in the concerned period since August 7, when Russia announced its ban on imports of selected food products from the West (Fresh Plaza, 2014). The above activities were probably the result of significant losses, which might have been suffered by the Czech producers because of significant inflow of food from other EU Member States following the Russian embargo (Ambroziak, 2017). According to the Czech authorities, the impact of the Russian embargo on the Czech producers of fruit and vegetables was estimated at between CZK 0.59 million and CZK 1.42 million (Prague Post, 2014).

Another control tool to the Czech market has been introduced under the Regulation of 1 July 2015. (No. 172/2015). As of April 2016, all entities importing agri-food products to the Czech market are required to submit very detailed reports for a minimum of 24 hours prior to the introduction of goods into circulation. This applies to products such as: fresh fruit (peaches and nectarines, pears, apples, plums, purple plums, oranges, bananas, table wine), fresh vegetables (onion and garlic, carrots and celery, tomato, pepper, cucumber salad, cabbage, cauliflower, broccoli), early and late potatoes, products made from grapes, on the basis of Regulation No. 1308/2013 and table wine, fresh wine other than table wine, poppy, dietary supplements (CAFIA, 2016). In addition to the data transmitted electronically (http://www.szpi.gov.cz/dovozy-prihlaseni. aspx) relating to the prices and place of their sale, the exporter is obligated to present a set of documents, including information about: quality of class/genre of agri-food products, country of origin and name and address of the manufacturer and recipient, as well as the date of import into the destination (CAFIA, 2016).

The above requirements, covering both additional controls and an obligation to notify about the delivery, are a typical non-tariff administrative barrier that can effectively and significantly hinder the free flow of goods and consequently limit the effect of trade creation. In addition, it seems that it may conflict with Regulation No. 882/2004, which provides that official inspections should treat importers and domestic suppliers equally; therefore, they should be held after the arrival of the products. In case of this category of barriers, the effects of their implementation is felt by all suppliers of goods to the market. The efficiency of the presented administrative barriers results from their interconnection - detailed and frequent inspection with an information to inform about deliveries. Consequently, the existing exporters, especially from the most often controlled countries, may look for new sales markets. This obviously requires certain investment and time since diagnosis 
of new arrivals, adapting to their needs and sometimes the relevant certificates and approvals is a long-lasting process. Hence, it is rare for existing suppliers to easily move their trade streams in agri-food products from one recipient to another.

\section{Trade in agri-food products from Poland to the Czech Republic}

Protectionist actions in trade in agri-food products may be especially visible between, on the one hand, a country that is not self-sufficient in this area and, on the other, the country that is a major supplier of the products. Such a pair of economic partners are undoubtedly the Czech Republic and Poland. In case of Poland, the problem is strengthened by the economies of scale, resulting in lower prices offered by domestic producers. At the same time, the Czech agri-food industry is not as well financed as Polish (thanks to the intensive pre-accession activities and efficient use of European funds for agriculture and rural development). As a result, Poland is the second, after Germany, biggest food exporter to the Czech Republic. This export gradually increased after the Polish accession to the EU. Dynamics of growth in sales of the Polish agri-food products to the Czech Republic was then higher than to the entire EU or to the third countries. This means that soft non-tariff barriers, such as the above-discussed cases of actual, over-publicised or erroneously identified Polish products as failing to meet the quality requirements or phytosanitary standards, revealed as of 2015, did not have a major impact on the growth of the dynamics of the Polish exports to the Czech market. The situation changed radically in 2016, when the Czech authorities introduced stringent administrative requirements that may be understood as traditional non-tariff barriers. These not only limited the interest in Polish products on the Czech market but also constrained the willingness of the Polish entrepreneurs to export to this market. The Polish entrepreneurs redirected their attention to other EU Member States (a clear growth in the dynamics of exports in the same period to the inter-EU market, including to the major recipients of the Polish food, i.e. Germany, the United Kingdom and Italy (Fig. 1 and 2).

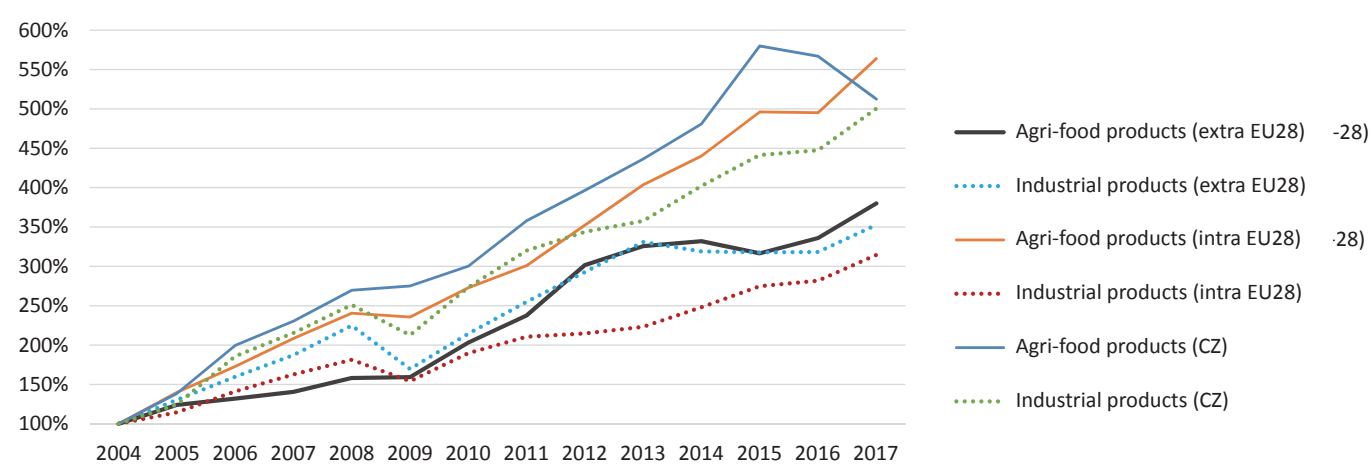

Fig.1. Dynamics of export from Poland to the Czech Republic and other countries worldwide between 2004 and $2017(2004=100 \%)$

Source: own elaboration based on Eurostat data. 


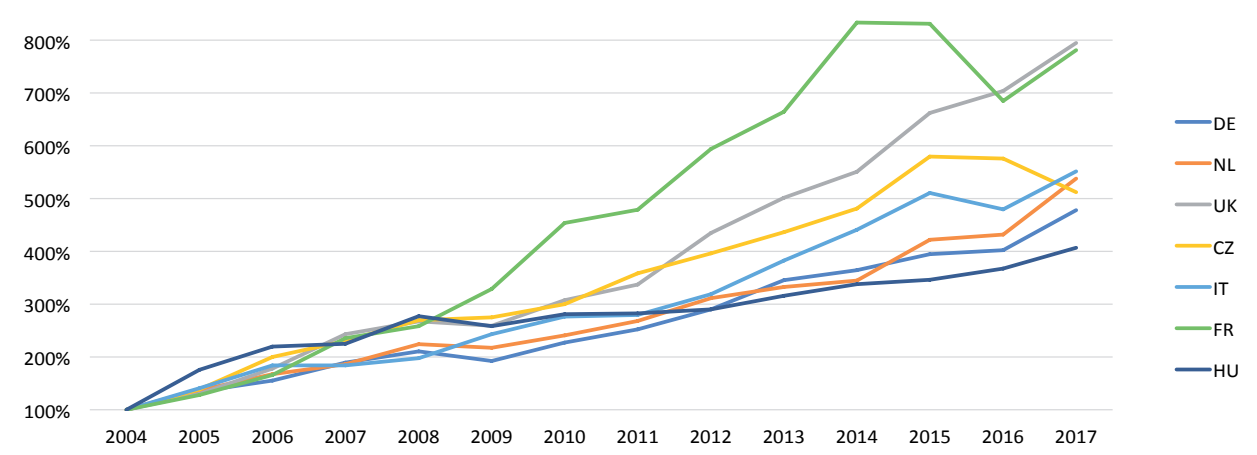

DE - Germany; NL - the Netherlands; UK - the United Kingdom; CZ - the Czech Republic; IT - Italy; FR - France.

Fig. 2. Dynamics of export from Poland to the key recipients of agri-food products from the EU between 2004 and $2017(2004=100 \%)$.

Source: as for Fig. 1.

The above hypotheses confirm the results of research on the Czech imports of agri-food products after accession to the European Union (Fig. 3). Over the last years, five major exporters of these products noted a constant growth of supplies to the Czech market (except for Slovakia, where the import dynamics has slowed down since 2012). In this period, Poland was a leader until 2015. In the next year, when the Czech Republic has introduced administrative requirements to notify goods in connection with burdensome inspection and negative experiences in relations with the Czech authorities, imports of agri-food products plummeted only in case of Poland (and to a slightly lower degree from Slovakia). Thus, achieving a certain reduction in the trade creation effect between Poland and the Czech Republic, at the same time, as noted before, redirecting these products to other EU Member States.

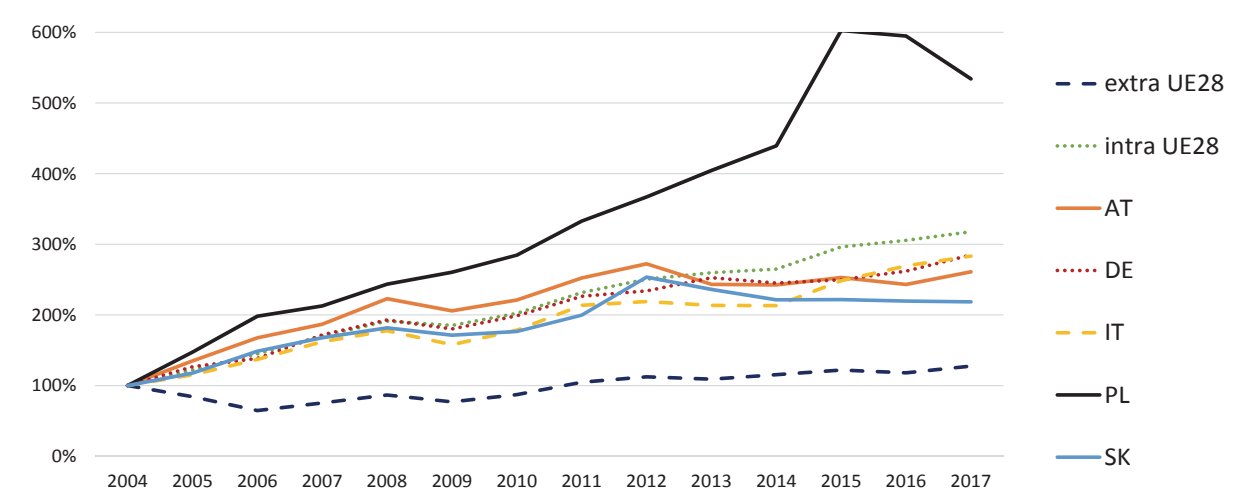

Extra EU 28 - trade of 28 EU Member States to non-EU countries; Intra EU 28 - trade of 28 EU Member States to the EU countries; AT - Austria; DE - Germany; IT - Italy; PL - Poland; SK - Slovakia.

Fig. 3. Dynamics of the Czech imports of agri-food products from the largest five suppliers from the EU.

Source: as for Fig. 1. 


\section{Conclusions}

The presented research may give raise to a question: to what extent the soft nontariff barriers introduced in the Czech Republic were addressed only at food from Poland and to what extent they were addressed at all major suppliers of agri-food products to the market. The discussed cases of actions discouraging the Czech consumers from buying Polish food based on negating the quality of Polish food products and challenging the compliance with the relevant sanitary requirements during production and transport of these products can suggest a multiannual campaign conducted by the Czech Republic against food from Poland. Consequently, the Polish food producers on several occasions addressed requests both to the Polish government and the European Commission underlining the existence of barriers to the EU internal trade which are contrary to the principles of the European Single Market. The most often used barriers for the Polish producers on the Czech market covered unjustified and frequent sanitary inspections and additional documentary and certification requirements. The issue of using unjustified non-tariff barriers and the necessity of their elimination was undertaken also, on the initiative of Polish producers, by the European Parliament (2016).

The analysis of statistical data on commodity flows between Poland and the Czech Republic allows us, however, to conclude that the introduction of soft nontariff barriers has not, so far, had a significant negative impact on the Polish exports of agri-food products to the Czech Republic. Thus, it seems that the main reason behind the popularity of the Polish food in the last decade can be price competitiveness of the Polish exporters. The Czech consumers, as most consumers in other countries, mainly seek food products at a lower price. It can be, however, presumed that in some cases the negative attitude towards Polish producers in the Czech Republic was justified. Increasing export of the Polish products to the Czech Republic allows us to conclude that the negative consequences were primarily borne by individual operators who sometimes indeed offered irregular products.

Only since 2016, when restrictive administrative barriers started to apply in the Czech Republic, a certain decrease in the volume of food imports from Poland has been noted. It may be the response of the market to the significant increase in the previous years or a way to discourage the Polish exporters with additional requirements and inspections. It cannot be ruled out that in the long run, certain transfers of trade from the Czech market may be expected in favour of, above all, the other EU Member States. But this may occur after a relatively longer period of impediments, as finding new outlets is very difficult, expensive and takes time to obtain appropriate certificates and permits (especially in trade outside the EU).

In conclusion, it is worth noting that the dynamics of import of agri-food products of major suppliers to the Czech market has not changed as much as in the case of Poland, despite the introduction of the obligation to inform about the intention to import in 2016. Thus, despite the introduction of administrative barriers on the Czech market, the activities of other major food importers are still very effective. The analysis of the causes of this phenomenon requires further research. 


\section{References}

Aitken, N.D. (1973). The Effect of the EEC and EFTA on European Trade: A Temporal Cross-Section Analysis. The American Economic Review, no. 63(5), pp. 881-892.

Ambroziak, A.A. (2017). Wpływ embarga Federacji Rosyjskiej na eksport jabłek z Polski w latach 2004-2015. Roczniki Ekonomii Rolnictwa i Rozwoju Obszarów Wiejskich, vol. 104, issue 1, pp. 22-29. DOI: 10.22630/RNR.2017.104.1.2.

Ambroziak, Ł. (2016). Efekt kreacji handle Polski z Kanadą po wejściu w życie umowy CETA. Unia Europejska.pl, no. 237(2), pp. 19-28.

Ambroziak, Ł., Kaliszuk, E. (2009). Strefa wolnego handlu Unia Europejska i Ukraina - skutki handlowe dla Polski. Gospodarka Narodowa, no. 11-12, pp. 141-163.

Balassa, B. (1961). The Theory of Economic Integration. Greenwood Press.

Balassa, B. (1966). Tariff Reductions and Trade in Manufacturers among the Industrial Countries. The American Economic Review, no. 56(3), pp. 466-473.

Balassa, B. (1967). Trade Creation and Trade Diversion in the European Common Market. The Economic Journal, no. 77(305), pp. 1-21.

Balassa, B. (1974). Trade Creation and Trade Diversion in the European Common Market: An Appraisal of the Evidence. Manchester School of Economic and Social Studies, no. 42(2), pp. 93-135.

Baldwin, R. (1989). The growth effects of 1992. Economic Policy, no. 9, pp. 247-282.

Barcz, J., Kawecka-Wyrzykowska, E., Michałowska-Gorywoda, K. (2016). Integracja europejska $w$ okresie przemian. Aspekty ekonomiczne. Warszawa: Polskie Wydawnictwo Ekonomiczne.

Burfisher, M., Robinson, S., Thierfelder, K. (2001). The impact of NAFTA on the United States. Journal of Economic Perspectives, no. 15(1), pp. 125-144.

CAFIA (2016). Notification of selected foodstuffs pursuant to Decree No. 172/2015 Coll. Retrieved from: www.szpi.gov.cz/en/article/notification-of-selected-foodstuffs-pursuantto-decree-no-172-2015-coll.aspx (access date: 5.04.2016).

Carbaugh, R.J. (2014). International Economics. Boston: CENGAGE Learning.

Ceskakvalita.cz (2018) Program Česká Kvalita. Retrieved from: www.ceskakvalita.cz/spotrebitele (access date: 18.02.2018).

Cheong J., Wong K. (2007). Economic Integration, Trade Diversion, and Welfare Change. Working Paper, University of Washington.

EU Office ĆS (2016) The transformation of Czech agriculture after entry into the EU, Businessinfo.cz, 12.7.2016. Retrieved from: http://www.businessinfo.cz/en/articles/thetransformation-of-czech-agriculture-after-entry-into-the-eu-80519.html (access date: 25.02.2018).

Fresh Plaza (2014). Czech Ag Minister disputes Polish claims. Retrieved from: www.freshplaza. com/article/132560/Czech-Ag-Minister-disputes-Polish-claims (access date: 18.02.2018).

Heath, A. (2012). Czechs want to ban the import of Polish food, CEE Packaging, 2 May 2012. Retrieved from: www.ceepackaging.com/2012/05/02/czechs-want-to-ban-the-import-ofpolish-food (access date: 25.02.2018).

Johnstone, C. (2016) Underpriced and over here: Czech egg producers complain about imports, Radio Praha in English, 14.07.2016. Retrieved from: www.radio.cz/en/section/business/underpriced-and-over-here-czech-egg-producers-complain-about-imports (access date: 23.02.2018). 
Juhảsz, L. (2016) Czech Republic Strengthens Local Food Labelling Rules. ESM - European Supermarket Magazine, 05.01.2016. Retrieved from: www.esmmagazine.com/czechrepublic-strengthens-local-food-labelling-rules/23164 (access date: 21.02.2018).

Kawecka-Wyrzykowska, E., Rosati, D. (2003). The Accession of Central European Countries to the European Union: The Trade and Investment Effects on Belarus, the Russian Federation and Ukraine., Economic Commission for Europe, Occasional Paper No. 2, Geneva.

Ładyka, S. (2001). Z teorii integracji gospodarczej. Warszawa: Oficyna Wydawnicza SGH.

Law of 24 June 1997 (110/1997) on food and tobacco products and amending and supplementing certain related laws as ammaned by the Law No. 139/2014 (Ustawa z 24 czerwca 1997 r. (110/1997) o produktach żywnościowych i tytoniowych nowelizująca i uzupełniająca część związanych z nią ustaw zgodnie z Ustawą nr 139/2014). Retrieved from: www.global-regulation.com/translation/czech-republic/507065/on-food-and-tobacco-products.html.

Lipsey, R.G. (1960). The Theory of Customs Unions: A General Survey. The Economic Journal, no. 70(279), pp. 496-513.

Magee, Ch.S.P. (2008). New measures of trade creation and trade diversion. Journal of International Economics, no. 75(2), pp. 349-362.

Makower, H., Morton, G. (1953). A Contribution Towards a Theory of Customs Unions. The Economic Journal, no. 63(249), pp. 33-49.

Marques, H. (2008). Trade and Factor Flows in a Diverse EU: What Lessons for the Eastern Enlargement(s)?. Journal of Economic Surveys, no. 22(2), pp. 364-408.

Molle, W. (2006). The Economics of European Integration: Theory, Practice, Policy. Aldershot, U.K. and Burlington, Vt.: Ashgate.

Panagariya, A. (2000). Preferential Trade Liberalization: The Traditional Theory and New Developments. Journal of Economic Literature, no. 38(2), pp. 287-331.

Parlament Europejski (2016) Sprawozdanie w sprawie barier pozataryfowych na jednolitym rynku (2015/2346(INI). Komisja Rynku Wewnętrznego i Ochrony Konsumentów, A8-0160/2016.

Pospihal, R. (2016) Nevyhovující čaj "Herbal tea (Loyd) - máta s brusinkou a bylinkami”, APiC, 30.12.2016.

Potravinynapranyri.cz (2017). Retrieved from: www.potravinynapranyri.cz/Search .aspx?ext=y\&sorigincountry $=172 \&$ lang=en $\&$ design $=$ default\&archive=actual\&listtype $=$ tiles $\quad($ access date: 18.02 .2018$)$.

Prague Post (2014). Russian food ban hits Czech farmers. Prague Post. Retrieved from: www. praguepost.com/food-and-drink/41406-russian-food-ban-hits-czech-farmers (access date: 25.02.2018).

Regulation No. 882/2004 of the European Parliament and of the Council of 29 April 2004 on official controls performed to ensure the verification of compliance with feed and food law, animal health and animal welfare rules, OJ L 165/2004.

Richter, J. (2013). Czech-Polish food row heats up, Radio Praha in English, 10-04-2013. Retrieved from: www.radio.cz/en/section/marketplace/czech-polish-food-row-heats-up (access date: 23.02.2018).

Rivera-Batiz, L.A., Romer, P.M. (1991). Economic Integration and Endogenous Growth. The Quarterly Journal of Economics, no. 106(2), pp. 531-555.

Salvatore, D. (2014). International Economics. Trade and Finance. Wiley.

Sapir, A. (2011). European Integration at the Crossroads: A Review Essay on the $50^{\text {th }}$ Anniversary of Bela Balassa's Theory of Economic Integration. Journal of Economic Literature, $n r$ 49(4): pp. 1200-1229. 
Spritzer, D., Bilefsky, D. (2012). Czechs See Peril in a Bootleg Bottle. The New York Times, 17.09.2012. Retrieved from: www.nytimes.com/2012/09/18/world/europe/czechs-banhard-liquor-sales-after-methanol-poisonings.html (access date: 25.02.2018).

Verdoorn, P. J. (1954). A Customs Union for Western Europe: Advantages and Feasibility. World Politics, no. 6(4), pp. 482-500.

Viner, J. (1950). The Customs Union Issue. London: Stevens and Sons.

Weststrate, C. (1948). The Economic Political Implications of a customs union. Quarterly Journal of Economics, no. 62(3), pp. 362-380.

Wonnacott, R.J. (1996). Free-Trade Agreements: For Better or Worse? The American Economic Review, no. 86(2), pp. 62-66.

WPHiI (2016). Zmiany zasad oznaczania czeskiej żywności. WPHiI Ambasady RP w Pradze, Biuletyn Informacyjny Styczeń 2016. Retrieved from: www.czechrepublic.trade.gov.pl/ pl/f/view/fobject_id:274360. 


\title{
MECHANIZMY BARIER POZATARYFOWYCH \\ W HANDLU ROLNO-SPOŻYWCZYM MIĘDZY POLSKAૃ A CZECHAMI W RAMACH RYNKU WEWNĘTRZNEGO UE
}

\begin{abstract}
Abstrakt
Celem niniejszego artykułu jest identyfikacja mechanizmów barier pozataryfowych wpływajacych na wewnatrzunijna wymiane produktami rolno-spożywczymi na przykładzie handlu między Polska a Czechami. Na wstepie przedstawiono główne założenia teoretyczne swobodnego przepływu towarów w oparciu o kolejne etapy integracji gospodarczej wedtug Balassa. Nastepnie omówiono wybrane przykłady zidentyfikowanych działań Czech $w$ odniesieniu do importowanych z Polski artykułów rolno-spożywczych wraz z analiza potencjalnych mechanizmów ekonomicznych będacych skutkiem tych działań. W kolejnej części przedstawiono efekty statystyczne prowadzonej wymiany handlowej, co pozwoliło sformułować wnioski dotyczace potencjalnych konsekwencji wprowadzanych barier.

Na podstawie przeprowadzonej analizy stwierdzono, że stosowane na rynku czeskim miękkie bariery pozataryfowe nie przyniosły znaczaco negatywnych skutków dla ogólnego importu polskich produktów rolno-spożywczych do Czech. Negatywne konsekwencje wprowadzanych barier ponosili pojedynczy przedsiębiorcy, którzy, według władz czeskich, oferowali produkty niespełniajace wymogów. Jednocześnie zidentyfikowano tradycyjne bariery administracyjne nałożone na wszystkich dostawców artykułów rolno-spożywczych na rynek czeski, które doprowadziły do załamania się eksportu z Polski, podczas gdy jednocześnie utrzymat się wzrost dynamiki głównych dostawców z innych państw członkowskich UE.
\end{abstract}

Słowa kluczowe: wewnątrzunijna wymiana handlowa, protekcjonizm, produkty rolno-spożywcze.

Accepted for print: 5.09.2018.

Unless stated otherwise all the materials on the website are available under the Creative Commons Attribution 4.0 International license.

Some rights reserved to the Institute of Agricultural and Food Economics - National Research Institute.

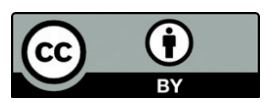

